University of Nebraska - Lincoln

DigitalCommons@University of Nebraska - Lincoln

1971

\title{
Experimental Hybridization of the New World Quail (Odontophorinae)
}

Paul A. Johnsgard

University of Nebraska-Lincoln, pajohnsgard@gmail.com

Follow this and additional works at: https://digitalcommons.unl.edu/biosciornithology

Part of the Ornithology Commons

Johnsgard, Paul A., "Experimental Hybridization of the New World Quail (Odontophorinae)" (1971). Papers in Ornithology. 59.

https://digitalcommons.unl.edu/biosciornithology/59

This Article is brought to you for free and open access by the Papers in the Biological Sciences at DigitalCommons@University of Nebraska - Lincoln. It has been accepted for inclusion in Papers in Ornithology by an authorized administrator of DigitalCommons@University of Nebraska - Lincoln. 


\title{
EXPERIMENTAL HYBRIDIZATION OF THE NEW WORLD QUAIL (ODONTOPHORINAE) ${ }^{1}$
}

\author{
Paul A. Johnsgard
}

Although the surprisingly high capacity for hybridization among species of the odontophorine genera Colinus, Callipepla, and Lophortyx has been recognized for some time (Gray, 1958), no systematic attempt has been made to produce and study such hybrid combinations. 'Those that have occurred have resulted under natural conditions or have been fortuitously produced by game breeders who were interested neither in the hybrids themselves nor in determining their relative fertility. As a result, the only positive information so far available on the fertility of hybrids among this group is that of Shore-Baily (1913), who obtained a brood of $F_{2}$ hybrids from an original cross between a male Scaled Quail (Callipepla squamata) and a female California Quail (Lophortyx californica). These secondgeneration birds died before their fertility could be determined. Hubbard (1966) reported a possible back-cross hybrid involving Scaled Quail backcrossed to Gambel's Quail (Lophortyx gambelii) taken in New Mexico. To my knowledge, no other case of successful hybridization beyond the first generation has been reported, although hybrid females of various intergeneric combinations have been known to produce eggs (Johnsgard, 1970).

To gain more satisfactory information on the possible fertility of such hybrids, and to study behavioral and morphological features of these birds, an effort has been made to breed interspecific hybrid combinations involving all of the North American species of these three genera. These include the Scaled Quail, Gambel's Quail, California Quail, Elegant or Douglas Quail (Lophortyx douglasii), and Bobwhite (Colinus virginianus). Also as the hybrid combination has twice been reported to occur in nature, the Mountain Quail (Oreorty $x$ picta) was crossed with the California Quail.

All birds were kept indoors in rooms provided with 17-hour photoperiods and temperatures ranging from about 70 to $80^{\circ} \mathrm{F}$. Two types of cages were used with equal success, including standard wood and wire-bottom quail breeding pens measuring $24 \times 24 \times 72$ inches, and entirely open welded wire cages approximately $18 \times 14 \times 48$ inches. Nest boxes were also provided, but the birds rarely used them. Eggs were collected daily, placed temporarily under cool storage in plastic bags, and set in an incubator at weekly intervals. The incubator was a forced-air model of commercial size with automatic turning, set for dry bulb and wet bulb readings of 99.3-

\footnotetext{
${ }^{1}$ Contribution No. 421 from the Department of Zoology, University of Nebraska, Lincoln, Nebraska 68508.
} 
$100^{\circ} \mathrm{F}$ and $83-88^{\circ} \mathrm{F}$ respectively. This setting, which is that recommended for domestic fowl eggs, gave good hatching success with an incubation period of slightly over 23 days for all quail species and hybrid combinations studied. Eggs were initially candled after 7 days, when infertile eggs and dead embryos ("early embryonic death" in Table 1) were removed. Subsequent prehatching mortality was recorded as late embryonic death, including failure to complete pipping.

Establishment of hybrid pairings was usually achieved with little difficulty. Whenever possible birds representing the desired crosses were placed together before they had reached sexual maturity, and in some instances as soon as they could be accurately sexed. Fully adult birds were also used, and with few exceptions they soon tolerated the new partner. Females that were already producing eggs sometimes did not interrupt their egg-laying schedule when placed with a new male, although none of the eggs dropped shortly after new pairings were made proved fertile. Serious injury or the death of a newly introduced female occurred in only a few instances, and could usually be avoided by early separation of noncompatible birds. Pair formation in all the species appears to consist of ritualized aggressive postures and inhibited attacks on the female, while the latter assumes submissive postures such as crouching. Differences in the vocalizations, postures, and plumage characteristics of the various species that may serve as isolating mechanisms under natural conditions are subjects of future studies and are not considered here.

\section{RESULTS}

Egg production, fertility, and viability.-A summary of incubation and rearing results appears in Table 1 . With few exceptions the number of eggs incubated is less than the total laid, as some eggs were cracked, used for albumen analysis, or not incubated for other reasons. As the table shows, success was achieved in rearing $F_{1}$ hybrids between the Bobwhite and Gambel's Quail, the Bobwhite and Scaled Quail, the Scaled and Gambel's Quail, the California and Scaled Quail, and between the California and Mountain Quail. Except for the first-named cross, all these combinations have previously been reported from the wild or captivity (Johnsgard, 1970). The fairly substantial losses of young of both hybrids and parental types stemmed primarily from two sources, cannibalism and accidental chilling. Even weekly bill-trimming failed to control completely losses from pecking, which caused the most severe losses. In no case was the death of any $F_{1}$ hybrid clearly attributed to a weakness at hatching. The weakest chicks at hatching were those of the Douglas Quail, of which only 4 out of 32 successfully completed pipping and none lived beyond a week. Likewise both the Scaled and Gambel's Quail young showed a surprisingly high incidence 
TABLE 1

Results of Incubation of Hybrid Quatl Eggs as Compared with Parental Species

\begin{tabular}{|c|c|c|c|c|c|c|}
\hline & $\begin{array}{c}\text { Total } \\
\text { eggs } \\
\text { incu- } \\
\text { bated }\end{array}$ & $\begin{array}{c}\text { Infer- } \\
\text { tile }\end{array}$ & $\begin{array}{l}\text { Early } \\
\text { embry- } \\
\text { onic } \\
\text { death }\end{array}$ & $\begin{array}{l}\text { Late } \\
\text { embry- } \\
\text { onic } \\
\text { death }\end{array}$ & Hatched & Reared \\
\hline \multicolumn{7}{|l|}{ Parental Species } \\
\hline Bobwhite (B) & 28 & 14 & 3 & 0 & 11 & 7 \\
\hline Gambel's (G) & 62 & 4 & 10 & 20 & 28 & 6 \\
\hline California $(\mathrm{C})$ & 76 & 35 & 39 & 2 & 0 & 0 \\
\hline Douglas (D) & 35 & 1 & 2 & 28 & 4 & 0 \\
\hline Scaled (S) & 83 & 16 & 16 & 26 & 1 & 6 \\
\hline Total Parentals & 290 & $70(24.1 \%)$ & $70(24.1 \%)$ & $76(26.2 \%)$ & $74(25.5 \%)$ & ) 19 \\
\hline \multicolumn{7}{|c|}{ Hybrid Pairings (male $\times$ female) } \\
\hline$B \times S$ & 110 & 43 & 16 & 11 & 40 & 12 \\
\hline $\mathrm{S} \times \mathrm{B}$ & 86 & 52 & 34 & 0 & 0 & 0 \\
\hline $\mathrm{C} \times \mathrm{S}$ & 47 & 21 & 4 & 3 & 19 & 14 \\
\hline $\mathrm{B} \times \mathrm{G}$ & 17 & 0 & 0 & 4 & 13 & 2 \\
\hline $\mathrm{S} \times \mathrm{G}$ & 16 & 5 & 0 & 4 & 7 & 1 \\
\hline $\mathrm{G} \times \mathrm{C}$ & 13 & 11 & 2 & 0 & 0 & 0 \\
\hline $\mathrm{G} \times \mathrm{S}$ & 9 & 6 & 2 & 0 & 1 & 0 \\
\hline $\mathrm{S} \times \mathrm{D}$ & 5 & 3 & 0 & 1 & 1 & 0 \\
\hline Mountain $\times \mathrm{C}$ & 34 & 27 & 0 & 4 & 3 & 1 \\
\hline Total $F_{1}$ Hybrids & 337 & $168(49.8 \%)$ & $58(17.2 \%)$ & $27(8.0 \%)$ & $84(24.9 \%)$ & 30 \\
\hline \multicolumn{7}{|l|}{ Other Hybrid Pairings } \\
\hline $\mathrm{F}_{1} \mathrm{BG} \times \mathrm{F}_{1} \mathrm{BG}$ & 16 & 6 & 10 & 0 & 0 & 0 \\
\hline $\mathbf{F}_{1} \mathrm{BG} \times \mathbf{G}$ & 28 & 0 & 28 & 0 & 0 & 0 \\
\hline $\mathbf{F}_{1} \mathrm{GS} \times \mathrm{F}_{1} \mathrm{GS}$ & 33 & 26 & 7 & 0 & 0 & 0 \\
\hline $\mathrm{S} \times \mathrm{F}_{1} \mathrm{GS}$ & 32 & 11 & 11 & 2 & 8 & 0 \\
\hline $\mathrm{F}_{1} \mathrm{CG} \times \mathrm{C}$ & 32 & 19 & 13 & 0 & 0 & 0 \\
\hline$F_{2} \mathrm{BC} \times F_{2} \mathrm{BC}$ & 74 & 52 & 22 & 0 & 0 & 0 \\
\hline $\mathrm{F}_{2} \mathrm{BC} \times \mathrm{B}$ & 25 & 15 & 10 & 0 & 0 & 0 \\
\hline $\mathbf{F}_{1} \mathrm{CS} \times \mathbf{F}_{1} \mathrm{CS}$ & 213 & 211 & 2 & 0 & 0 & 0 \\
\hline $\mathbf{F}_{1} \mathrm{BS} \times \mathrm{F}_{1} \mathrm{BS}$ & 228 & 228 & 0 & 0 & 0 & 0 \\
\hline $\mathrm{BW} \times \mathrm{F}_{1} \mathrm{BS}$ & 44 & 28 & 6 & 10 & 0 & 0 \\
\hline $\mathrm{S} \times \mathrm{F}_{1} \mathbf{B S}$ & 15 & 15 & 0 & 0 & 0 & 0 \\
\hline Total Other Hybrids & 740 & $611(82.6 \%)$ & $109(14.7 \%)$ & $12(1.6 \%)$ & $8(1.1 \%)$ & 0 \\
\hline
\end{tabular}

of late embryonic mortality. The low fertility and high incidence of early embryonic death in California Quail apparently was the result of a subfertile male in the single intraspecies pair that was established for California Quail.

The "other hybrid pairings" included in Table 1 consist mainly of attempted $\mathrm{F}_{2}$ production or of backcross pairings. Records are also included 
from pairings of four $F_{2}$ Bobwhite $\times$ California Quail hybrids that were obtained from the San Joaquin Game Farm, Reedley, California. According to the manager, R. Davis (in litt.), these four hybrids (two of each sex) were the only ones that hatched from a very large number of eggs laid by a pair of $F_{1}$ birds reared at that farm. I was unable to obtain the $F_{1}$ birds, but did purchase the $\mathrm{F}_{2} \mathrm{~s}$. Both females laid considerable numbers of eggs (one produced 21 eggs in 21 days, the other 103 eggs in 137 days), all of which were abnormally small (average of 10 is $27.1 \times 20.0 \mathrm{~mm}$ ). Of the 74 eggs set, none exhibited embryonic development beyond the very earliest stage. The only successful second-generation hybrid production thus far achieved in our laboratory has been the hatching of eight backcross hybrids (none surviving beyond 6 days) that resulted from pairing a male Scaled Quail to a female $F_{1}$ Gambel's $\times$ Scaled Quail. Earlier attempts to obtain $F_{2}$ offspring from the $F_{1}$ generation were unsuccessful. These $F_{1}$ birds had been produced by William S. Huey, who informed me (in litt.) that he too had been unable to obtain $\mathrm{F}_{2}$ birds, but did hatch a number of chicks when a Scaled Quail male was in the pen along with two $F_{1}$ females and a single $F_{1}$ male. These results suggest that at least a limited degree of hybrid fertility exists in Scaled $\times$ Gambel's Quail crosses, for which there was only suggestive evidence earlier (Hubbard, 1966). The $\mathbf{F}_{1}$ Gambel's $\times$ Scaled Quail female in our laboratory has laid typical-sized eggs at normal intervals (31 eggs in 63 days, compared with three Gambel's Quail that averaged 41 eggs in 97 days and three Scaled Quail that averaged 32 eggs in 67 days).

The possible fertility of the Scaled $\times$ California Quail cross, as reported by Shore-Baily (1913), has not yet been confirmed. Three of the seven females reared have laid, but the eggs have shown no embryonic development beyond 3 or 4 days or have been infertile. The eggs of the first breeding cycle were slightly smaller than normal (average of 10 is $28.6 \times 22.5$ $\mathrm{mm}$ ), while later eggs laid by the same females were of virtually normal size, averaging $32.6 \times 24.7 \mathrm{~mm}$.

The Bobwhite $\times$ Gambel's Quail hybrid appears definitely to be sterile. All the eggs laid by the only female reared of this cross were distinctly smaller than normal (average of 10 is $24.7 \times 19.5 \mathrm{~mm}$ ). None of the eggs representing potential $\mathrm{F}_{2}$ offspring developed beyond the earliest embryonic stages, and when the $\mathbf{F}_{1}$ male was later paired with a female Gambel's Quail all of the resulting fertile eggs also suffered early embryonic death.

The Bobwhite $\times$ Scaled Quail hybrids that have been reared are apparently sterile, at least inter se. All six females have laid eggs but most of these are distinctly smaller than normal (average of 10 laid by three females is $21.5 \times 16.6 \mathrm{~mm}$ ), and only one female has produced eggs of nearly normal size. Further, all the eggs these females produced have proved either infertile or have in any case shown no detectable embryonic development. It is 
of interest that in this cross, as well as the Scaled $\times$ California cross, no obvious excess of males has been noted (collectively 14 males and 13 females have been reared to maturity). Excessive males are frequently encountered in many intergeneric galliform hybrids and apparently are a reflection of a sex chromosome imbalance, causing differential sex mortality or sex reversal (Sandnes and Landauer, 1938).

It has not been possible to determine the fertility of the single male $F_{1}$ Mountain $\times$ California Quail that has been reared, as the female California Quail it was paired to has produced no eggs.

The results of these studies to date are similar to those of Morejohn (1968), who found that in crosses between two congeneric species of junglefowl (Gallus) the $\mathrm{F}_{1}$ offspring had high hatchability and were vigorous, but laid smaller-than-normal eggs and exhibited high embryonic mortality, with no $\mathrm{F}_{2}$ birds surviving to maturity. He did, however, succeed in hatching and rearing a few backcross offspring.

Inheritance of plumage characteristics.-Considering the diverse array of crest shapes, head patterning, and body feather coloration in the New World quail, the plumages of the hybrids are of special interest. Earlier published illustrations of adult hybrids among this group include photographs of both sexes of Bobwhite $\times$ Scaled Quail skins (McCabe, 1954), the skin of a male (probably a backcross) Scaled $\times$ Gambel's Quail (Hubbard, 1966), and a mounted Scaled $\times$ Douglas Quail (Banks and Walker, 1964). A photograph of the Bobwhite $\times$ Gambel's cross produced in our laboratory has appeared (Johnsgard, 1970), and monochrome illustrations of Mountain $\times$ California Quail hybrid males have been published (Peck, 1911; Peterle, 1951). A color painting of this same cross, in addition to male California $X$ Gambel's Quail and Gambel's $\times$ Scaled Quail, has also appeared (Hachisuka, 1928). Finally the Scaled $\times$ California hybrids Shore-Baily (1916) reared have been illustrated and a photograph of a captive male Scaled $\times$ Gambel's Quail appeared on the cover of the Arizona Game and Fish Department's "Wildlife views" for November-December 1966.

Before considering adult plumages, the natal plumages are worthy of attention. Of the parental species, the Bobwhite natal pattern is easily the most distinctive, with its broad, dark chestnut dorsal stripe that lacks a definite medial line and is indistinctly separated from the mottled woodbrown and buff upperparts by narrow cinnamon lines. The Scaled Quail and the two U. S. species of Lophortyx (as well as L. douglasii) are all extremely similar, and it is sometimes difficult to identify downy young of these species. All have small crests and a conspicuous light mid-dorsal line bordered on both sides with fuscous, the latter in turn bordered with wider buffy or cinnamon-buff lines that extend from the sides of the tail to the neck. Mountain Quail downy young somewhat resemble Bobwhites in that 


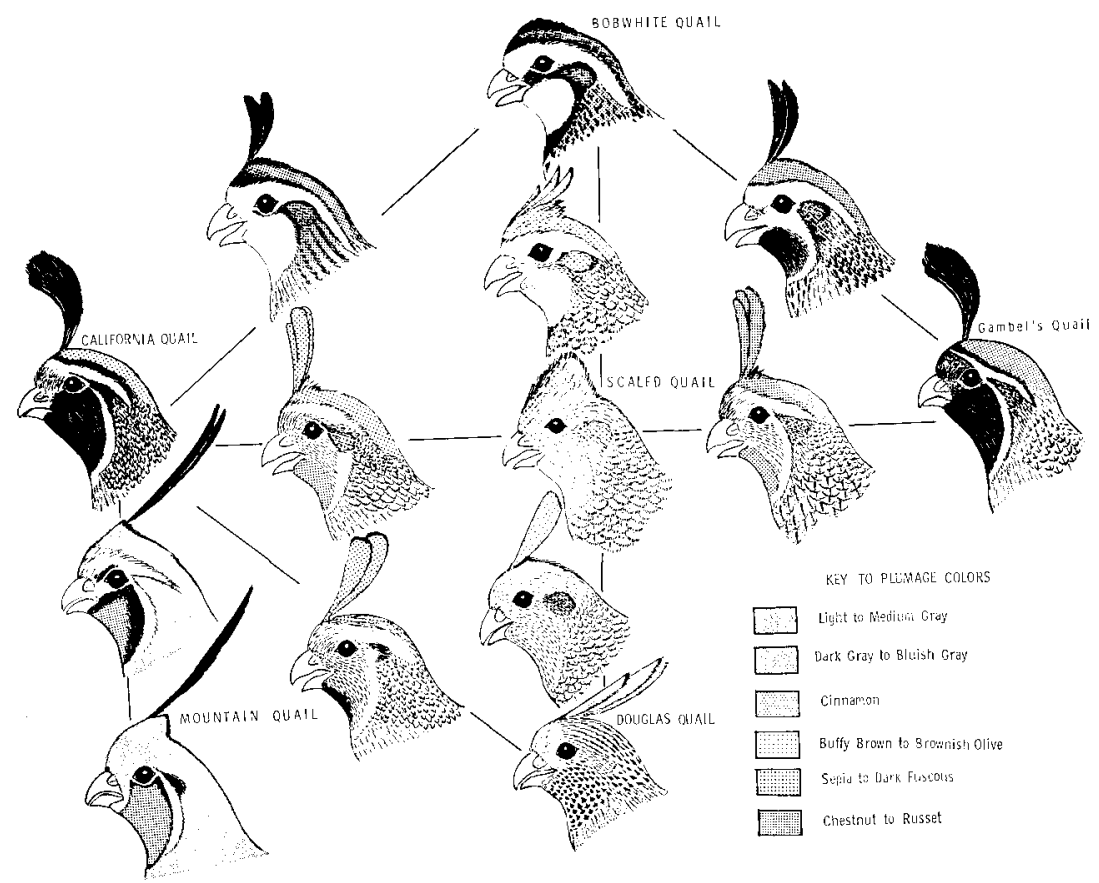

Figure 1. Diagram of adult male plumage patterns of six species of quail and eight intergeneric hybrids, with lines connecting hybrid combinations and parental species. Some variation occurred among the Scaled $\times$ California males which is not indicated here (see text).

they usually lack crests at hatching (but acquire them within a week), have a dark postocular stripe extending down the side of the neck, and have a distinctly chestnut rather than fuscous dorsal area that darkens to blackish laterally. The black is in turn bordered by narrow buffy-white lines, below which are a second pair of blackish lines, reminiscent of Lophortyx. In all cases the hybrid downy young have been exactly intermediate between the parentals.

Differences in the adult male plumage patterns of the hybrids are more difficult to present without color plates. They are largely limited to the head, lower breast, and flanks, all of which are utilized in sexual display. Differences in the dorsal surface, wings, tail, and tail coverts are either relatively negligible or are understandable in relation to differences in the other areas mentioned. The head plumage conditions are summarized in Figure 1, which illustrates the adult male heads of the six species studied, all the $F_{1}$ hybrid combinations obtained in this study, and two additional crosses (California $\times$ Douglas Quail and Scaled $\times$ Douglas Quail) that 
have been bred previously. The drawing illustrating the first of these crosses was based on a specimen (No. 458926) in the American Museum of Natural History, while the Scaled $\times$ Douglas Quail drawing is based on the photo published by Banks and Walker (1964). Not shown is the California $\times$ Gambel's Quail cross, which not only has already been illustrated (Hachisuka, 1928) but also is of little interest because of the great similarity of the parental species.

Although the drawings in Figure 1 represent the breeding plumage, it is of interest that, in some of the hybrid crosses reared, a distinctive subadult plumage immediately followed the juvenal plumage. Thus the male Bobwhite $\times$ Gambel's Quail temporarily exhibited an entirely white throat after molting its buffy juvenal plumage, but within a few weeks began replacing these feathers with black in the chin region, a condition that has persisted in succeeding molts. Similarly the male Mountain $\times$ California Quail initially had an entirely black throat immediately after its postjuvenal molt, but this was later permanently altered to a chestnut throat with a narrow black border. These two instances, and one mentioned below, support the view originally proposed by Dwight (1900) but questioned by Raitt (1961), namely that a limited prenuptial molt occurs in the chin and head region in Colinus, Lophortyx, and probably also Oreortyx. In general the ultimate color and head pattern of the hybrids is intermediate between the parental species, with a few interesting exceptions. In both the Scaled $\times$ Gambel's Quail and the California $\times$ Scaled Quail males the chin and upper throat are predominantly chestnut, being somewhat brighter in the former cross and virtually the same color as the crown of male Gambel's Quail. In two of the six California $\times$ Scaled Quail males the throat became almost entirely black when the birds were between 6 and 7 months old. The crest and anterior portion of the crown of the Scaled $\times$ Gambel's Quail male are chestnut, whereas in the California $\times$ Scaled Quail hybrid these areas are more fuscous. In both hybrid combinations the abdomen of the adult male is chestnut too, brighter than in male California Quail and similar to that of the castanogastris race of Scaled Quail. These color conditions have previously been illustrated in Hachisuka's (1928) plate, although the crest shape in that plate is not typical of our specimens or of the specimen Hubbard (1966) illustrated.

Crest shapes and lengths of the hybrids are also of interest, particularly among those involving distinctly crested and relatively crestless species. For example in the Bobwhite $\times$ Scaled Quail males a crest condition occurs that is strongly reminiscent of that found in the Crested Bobwhite (Colinus cristatus), which is reinforced by a facial pattern much like those of such Central American races as C. c. leucopogon. Ohmart (1967) has already 


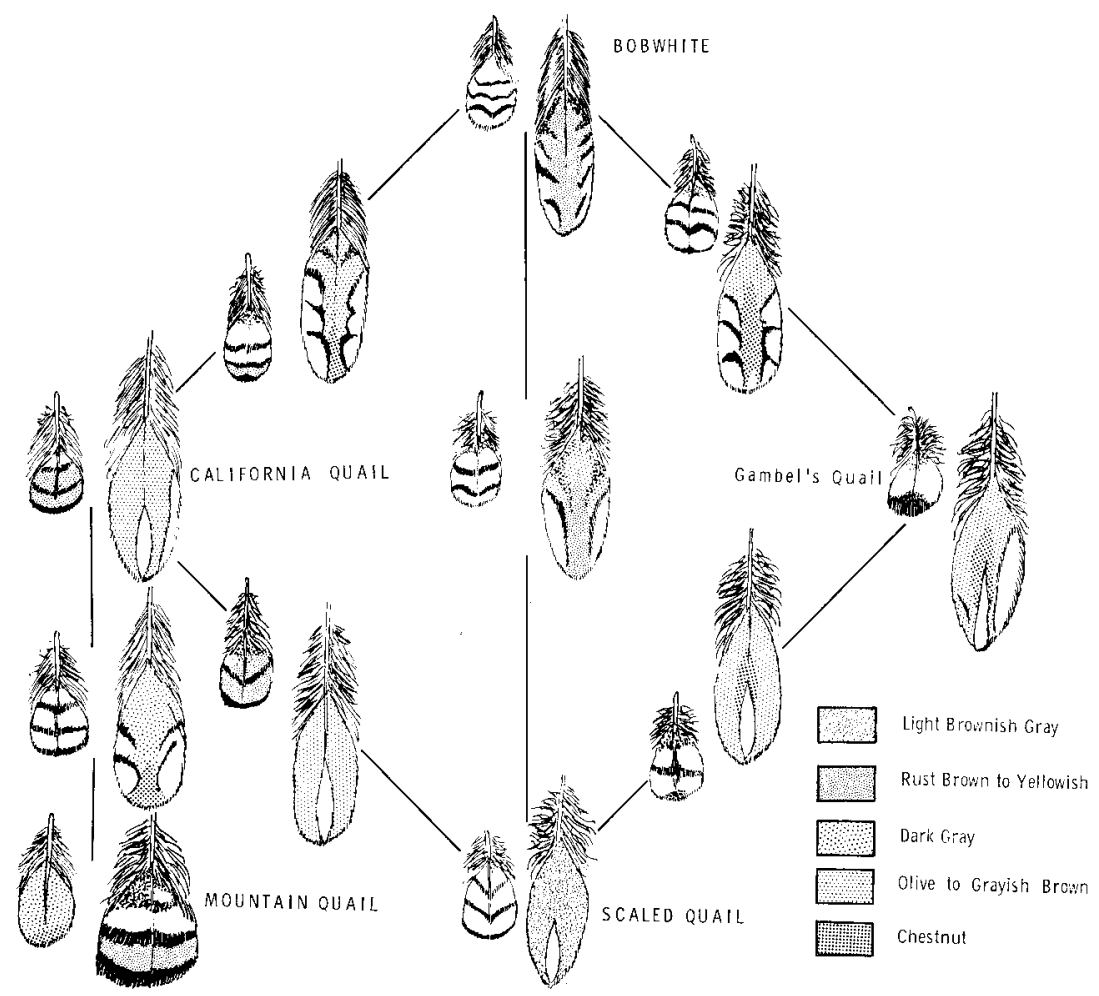

Figure 2. Upper abdomen and flank feathers from males of five species of quail and six intergeneric hybrid combinations. Lines connect hybrid combinations with parental types.

pointed out that even in the relatively bushy-crested Scaled Quail a pterylographic crest pattern of 10 feathers may be detected, which assumes a conspicuous form in the Bobwhite $\times$ Scaled Quail cross.

In spite of the strikingly different body and flank patterns in males of the parental species, examination of individual feathers from the upper abdomen and flanks and those of the available hybrid combinations (Figure 2) reveals the relatively simple variations in pigmentation configurations that are the bases for these differences. Thus the distinctive "scaling" of the Scaled Quail breast and abdomen is achieved by the shifting of the subterminal black band to the feather tip, whereas in Gambel's Quail males this melanistic deposition spreads over most of the feather, as is also the case in the Mountain Quail. The distinctive flank streaking of the Scaled, 


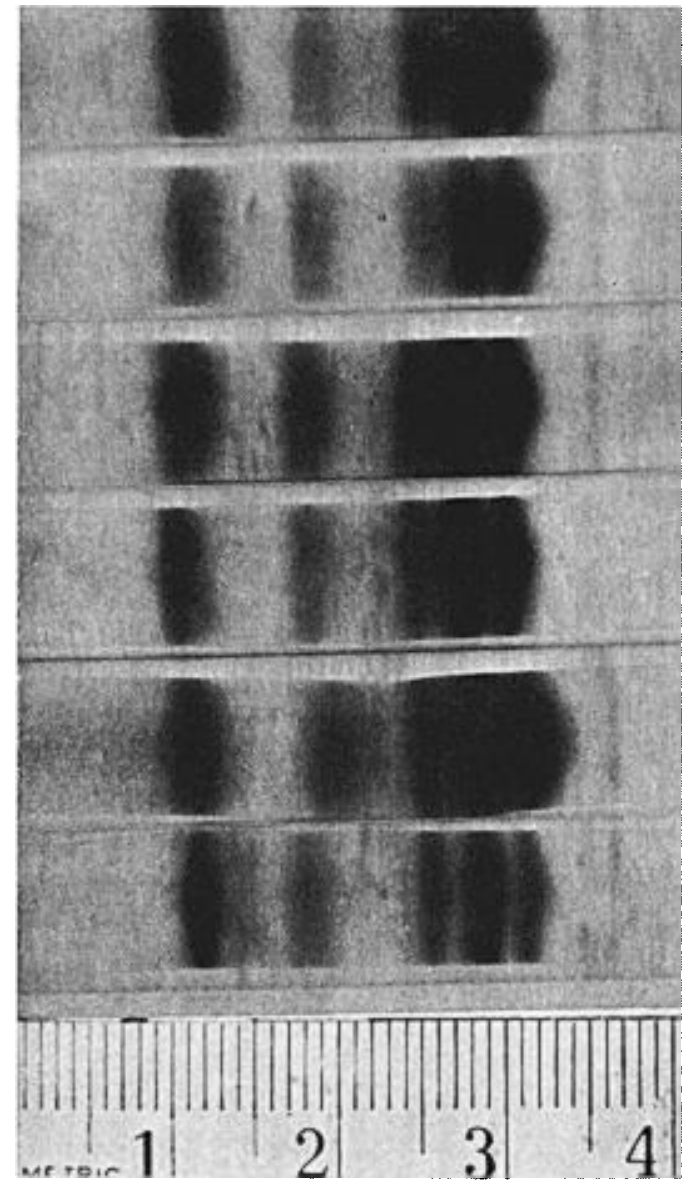

Figure 3. Acrylamide gel separations of albumen from (top to bottom) Douglas, California, Gambel's, Scaled, Bobwhite, and Crested Quails. Anodal movement is from left to right, with major visible fractions present representing ovoconalbumin, ovomucoid, and a triple ovalbumin. An unknown fraction between $\mathrm{cm} 3$ and 4 is also present.

Gambel's, and California Quails are produced by lighter shaft-streaks, whereas the spotted flanks of the Douglas Quail (not illustrated) are the result of elongated vane spots (Banks and Walker, 1964), and the barred flanks of the Mountain Quail are achieved by feather widening and an exaggeration of the transverse banding that may be detected in the Bobwhite. Interestingly, the male hybrids involving the Bobwhite with the Gambel's and California Quail have flanks that achieve the spotted condition of the Douglas Quail and also are nearly identical with the characteristic spotted flanks of the Crested Quail. 
Egg-white proteins.-The pioneering survey by Sibley (1960) on the egg-white proteins of birds included electrophoretic patterns representing 42 species of Galliformes, including all of the parental species considered in the present paper, as well as a Gambel's $\times$ Scaled Quail $F_{1}$ hybrid sample. His results of electrophoresis on a paper substrate indicated that the New World quail species studied exhibit a dense, usually triple, ovalbumin peak that undergoes considerable anodal movement at $\mathrm{pH}$ 8.6, a second major ovoconalbumin fraction that travels only a short distance, and a third anodal component between these that presumably corresponds to the ovomucoid component of domestic fowl (Gallus gallus) as illustrated by Sibley and Johnsgard (1959). The cathodally-migrating lysozyme fraction is readily visible in Sibley's paper separations, but the globulins are not distinguishable on the profiles he published. With the possible exception of the Mountain Quail, all the published profiles were extremely similar and Sibley attempted no detailed comparisons among them.

Through the cooperation of C. Michael Cowan, disc electrophoretic separations using a polyacrylamide gel medium have so far been made for all the six species considered in this paper, as well as the Harlequin Quail (Cyrtonyx mearnsi), a Colombian race of Crested Bobwhite (C. cristatus decoratus) and five intergeneric hybrid combinations. The procedure used was that described by Clarke (1964), except that minor buffer modifications produced an electrode buffer of $\mathrm{pH} 8.3$ and a gel buffer of 8.9 (Cowan, 1968). Thus the resulting separations should be closely comparable to those obtained by Sibley at a $\mathrm{pH}$ of 8.6 and a paper substrate, and this appears to be the case. All samples done so far additionally show a distinctive but minor fraction that migrates beyond the ovalbumin complex. This latter component is triple in all species and their hybrids. The Crested Bobwhite appears to be separable from the Bobwhite on the basis of a reduced anodal ovomucoid movement, and is closer to the other non-Colinus species in this respect than is the Bobwhite. Hybrids between the Bobwhite and the Gambel's, Scaled, and California Quails have ovomucoid components with intermediate migration properties, but their differences are slight. All of the separations are obviously extremely similar and suggest very close evolutionary relationships (Figure 3 ).

\section{ACK NOWLEDGMENTS}

This study was financed by a National Science Foundation research grant (GB7666X) and the University of Nebraska. Assistance in data-gathering and care of birds was provided by Daniel Hatch, Alice Prososki, and Raymond Goldstein. Electrophoretic separations were obligingly performed by Michael Cowan of Nebraska Wesleyan University. My sincere appreciation is extended to all these individuals and institutions. 


\section{SUMMARY}

Hybridization experiments among six species of New World quail currently placed in four genera (Colinus, Callipepla, Lophortyx, and Oreortyx) involved the establishment of nine mixed-pair combinations. Seven of these combinations resulted in the production of $F_{1}$ offspring, and individuals representing five intergeneric crosses have been reared to maturity. These $\mathrm{F}_{1}$ individuals exhibited a hatchability at least as high as occurred in parental species matings. In four of five intergeneric crosses, the hybrid females have laid smaller-than-normal eggs in spite of average or higherthan-average egg production, and a high proportion of eggs females laid have been infertile or suffered early embryonic death. Limited hybrid fertility has been established for one Colinus $\times$ Lophortyx and two Callipepla $\times$ Lophortyx combinations. Downy and adult plumage patterns of hybrids are generally intermediate and provide clues as to the probable evolution of plumage diversity in the group. Egg-white proteins of eight odontophorine species and five hybrid combinations were analyzed electrophoretically and exhibited great similarity, further suggesting close evolutionary relationships.

\section{Literature Cited}

Banks, R. C., ANd L. W. Walker. 1964. A hybrid Scaled $\times$ Douglas Quail. Wilson Bull., 76: 378-380.

ClaRk, J. T. 1964. Simplified disc (polyacrylamide gel) electrophoresis. Ann. New York Acad. Sci., 121: 428.

Cowan, C. M. 1968. The blood proteins of the bull shark Carcharhinus leucas. Unpublished Ph.D. dissertation, Lincoln, Univ. Nebraska.

DwIGHT, J., JR. 1900. The moult of the North America Tetraonidae (quails, partridges and grouse). Auk, 42: 34-51; 143-166.

Gray, A. P. 1958. Bird hybrids. Farnham Royal, Commonwealth Bureau.

Hachisuka, M. 1928. Variations among birds (chiefly game birds). Suppl., Publ. Ornithol. Soc. Japan, No. 12.

HubBard, J. P. 1966. A possible back-cross hybrid involving Scaled and Gambel's Quail. Auk, 83: 136-137.

Jomnsgard, P. A. 1970. A summary of intergeneric New World quail hybrids, and a new intergeneric hybrid combination. Condor, 72: 85-88.

MCCABE, R. A. 1954. Hybridization between the Bob-white and Scaled Quail. Auk, 71: 293-297.

MorejoHn, G. V. 1968. Breakdown of isolation mechanisms in two species of captive junglefowl (Gallus gallus and Gallus sonneratii). Evolution, 22: 576-582.

Ohmart, R. D. 1967. Comparative molt and pterylography in the quail genera Callipepla and Lophortyx. Condor, 13: 149-151.

PeCK, M. E. 1911. A hybrid quail. Condor, 13: 149-151.

Peterte, T. J. 1951. Intergeneric galliform hybrids: A review. Wilson Bull., 63: 219-224.

RaitT, R. J., JR. 1961. Plumage development and molts of California Quail. Condor, 63: 294-303. 
Sandnes, G. C., and W. Landauer. 1938. The sex ratio in the cross of Phasianus torquatus $q \times$ Gallus domesticus $\hat{\delta}$. Amer. Naturalist, 72: 180-183.

SHORE-BaILy, W. 1913. Fertility of hybrid quail. Bird Notes, 4: 326.

Shore-BaIly, W. 1916. Hybrid Squamata $\times$ Californian Quail. Bird Notes, 7: 149.

Sibley, C. G. 1960. The electrophoretic patterns of avian egg-white proteins as taxonomic characters. Ibis, 102: 215-284.

Stbley, C. G., AND P. A. Johnsgard, 1959. An electrophoretic study of egg-white proteins in twenty-three breeds of the domestic fowl. Amer. Naturalist, 93: 107115 .

Department of Zoology, University of Nebraska, Lincoln, Nebraska 68508. Accepted 25 February 1970. 